\title{
Evaluating the Water Quality Contribution of Estero de Paco to Pasig River and Manila Bay, Philippines
}

\author{
Eligia D. Clemente ${ }^{1^{*}}$ \\ ${ }^{1}$ Environmental Engineering Program, University of the Philippines, Diliman 1101, Quezon City, Philippines \\ Department of Mining, Metallurgical and Materials Engineering, University of the Philippines, Diliman 1101, QC
}

\begin{abstract}
The clean-up of the river system feeding into Manila Bay is crucial in addressing the current Manila Bay water quality. Since Estero de Paco is a feeder into Pasig River which enters the Manila Bay, its clean-up is imperative to sustain Manila Bay water quality. This research gathered information on the water quality Estero during both the dry and the wet season. Initial survey of the stretch showed that there are bridges and residential areas as potential sampling points. Using the Streeter-Phelps model an assessment of the water quality during different meteorological conditions shows that almost no DO is available during the dry season, while some have a DO $>5 \mathrm{mg} / \mathrm{l}$ (standard) during the rainy season. Unfortunately, based on the other critical parameters, Biochemical Oxygen Demand (BOD) was high due to discharge of septic waste directly into the river during the heavy rains. Sludge near populated areas were characterized and found to contain high levels of Oil \& Grease, Organic Matter. The Streeter-Phelps equation used to evaluate the oxygen deficit shows that at the Pasig River junction DO is negligible even during the wet season. It is recommended that regular monitoring and community engagement be actively pursued.
\end{abstract}

\section{Introduction}

The Philippines is an archipelago consisting of a network of islands, the biggest of which is Luzon in the northern part. The island is surrounded by the Philippine Sea in the east and the West. A network of rivers in the main island drains out to the Manila Bay which is the largest body of water in the main island which influences the quality of the water flowing out on the Western side. At the center of the Southeastern provinces, the heart-shaped Laguna de Bay spanning the provinces in the Southern part of the island meets up with the Pasig River before it flows out to the Manila Bay. During the dry season (January to May), Laguna Bay is relatively calm and contained, but during the rainy season its waters drain out to the Pasig River and flows out to the Manila Bay.

\subsection{The Pasig River}

The Pasig River is a $27-\mathrm{km}$ stretch of water with headwaters located at the mountains of Laguna [1] and runs across the heart of Metro Manila, through the busiest cities before going out to the Manila Bay. It is an estuary which connects the two major bodies of water, Manila Bay and Laguna Bay. Several tributaries contribute its waters to Pasig River and are home to Informal Settler Families (ISF) which contribute to the poor water quality condition of the Pasig River system.

In the early 1990s, the United Nations Environmental Program initiated a study of the environmental state of our river systems. The study showed that tidal flows influence the direction of water from the Pasig River, either flows out to the Manila Bay during the low tide or flows inward towards Laguna de Bay on high tides [2]. That study officially classified the Pasig River as well as its tributaries as dead rivers which led to the establishment of the Pasig River Rehabilitation Commission to lead the river clean-up and dredging.

\subsection{The Estero de Paco}

Four major tributaries among nineteen identified water bodies which contribute to more than $50 \%$ of the Biological Oxygen Demand (BOD) load of the Pasig River have been identified. These are the San Juan River, the Estero de San Miguel, the Estero de Binondo and the Estero de Paco. All the tributaries are located in Metro Manila and are home to several ISFs with no formal septage containment systems available.

The Paco district is a center of commercial activities and one of the largest public markets is located near the banks of the Estero. The Paco Market has been the center of commercial trading [3] as far back as the eighteenth century and has grown since. The largest parochial school in South East Asia is directly across the Paco market, on the other side of the river. With a student population of 4000 , its diel population increases to more than 5000 with the staff and parents during weekdays. Moreover, the estuary runs through several industrial areas as it flows out to meet with the Pasig River. Figure 1 shows the location of the Estero de Paco and its proximity to the mouth of the Pasig River. Due to the severity of the

* Corresponding author: edclemente $\underline{\text { eup.edu.ph }}$ 
conditions at the area, this was one of the first tributaries to get the attention of the Pasig River Rehabilitation Commission (PRRC). Loads of solid waste were hauled and several remediation technologies were put in place. Most of the ISFs were relocated and the shanties removed. This improved the situation of the waterway. For a while, despite the heavy rains, no flooding was experienced in the roads beside the Estero. There was also a pumping station placed near the junction of Estero de Paco and Pasig River to control the water flow coming in during high tide.

\subsection{The Manila Bay}

The Manila Bay is the ocean portal and seaport hub of Metro Manila for incoming and outgoing local and international cruises, freights and trade vessels and currently serves as epicenter for government trade and industry [4]. Currently, the Manila Bay has been the focus of attention of the National Government due to the loads of solid waste being dumped onto the bayside immediately after heavy rains and typhoons. It was also established that pollution not only manifested as solid waste but also as pollutants such as heavy metals, persistent organic pollutants, pesticides and organic loading from septic wastes and were contributed by nearby estuaries from the metropolis [5,6]. A focus on the clean-up of the bay and its known tributaries which include the Malabon River, Pasig River, Las Pinas River and the Ylang-ylang-Imus River System was thus declared. The Pasig River is the largest of these rivers and contribute the most BOD load to Manila Bay mainly due to the contribution of its own tributaries.

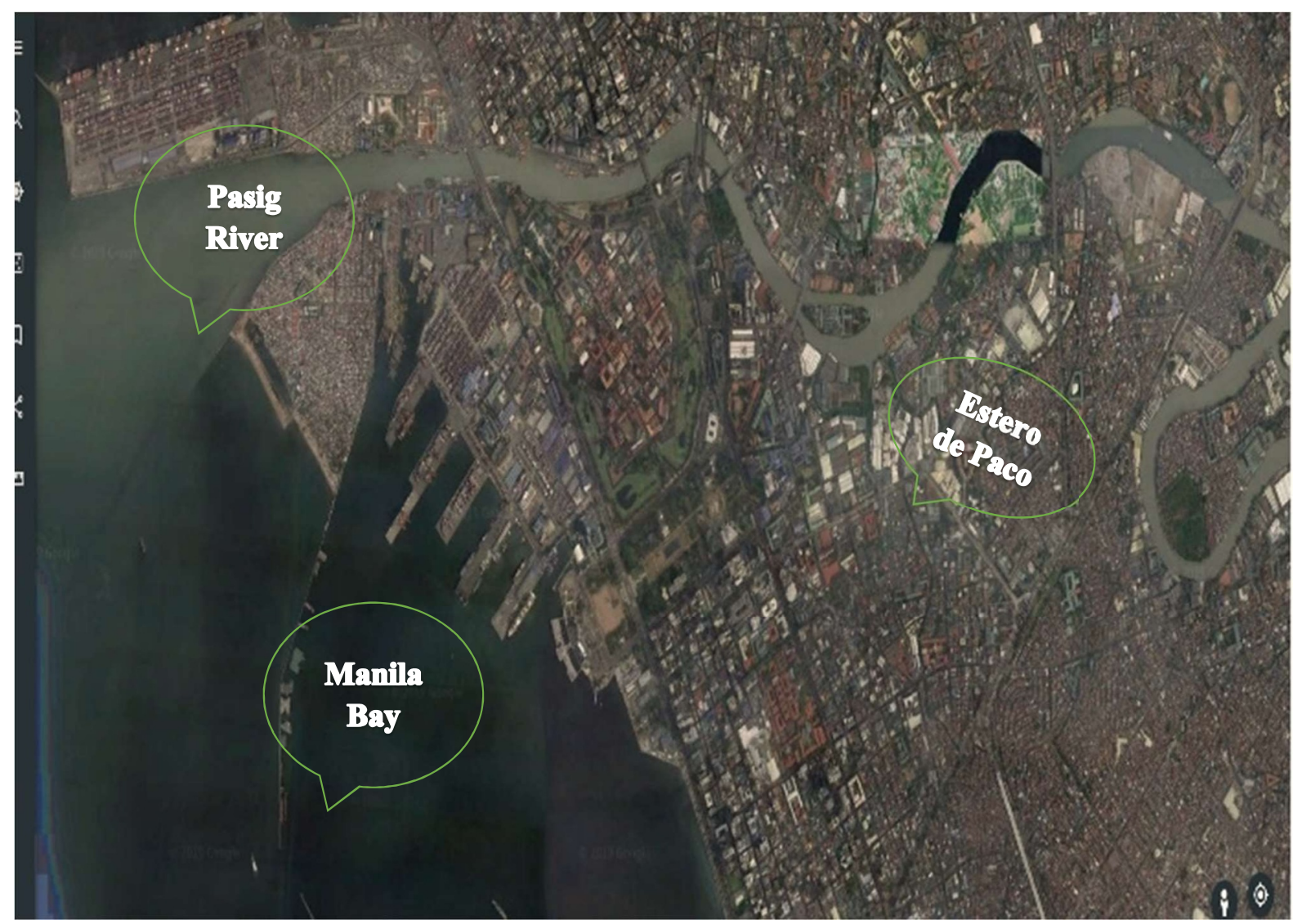

Fig. 1 Pasig River and Manila Bay. (Google maps).

\section{Review of Literature}

Surface water quality is greatly influenced by natural and anthropogenic events which may cause both positive and negative effects. Streams and rivers are the most vulnerable types of surface waters since the location is most often in the middle of a populated habitat.

In Uganda, the Kampala River runs through the heart of Kampala City where an urban settlement for informal settlers have poor or no solid waste or sewage facilities [7]. In China, several authors have been studying the Yangtze River and its conditions, and Yang [8] found that the Water Quality Model (WQM) of the Yangtze was highly influenced by nitrification. Eisakhani [9] used a GIS-based WQM assisted in quantifying non-point sources of pollution while Ling, et al [10] measured the impact of shrimp farming effluents from the residential areas located near the Selang Sibu River.

WQMs made use of Dissolved Oxygen as the parameter to evaluate the water quality and these were then used for policy making to address the pollution loads concerned. 


\subsection{Physico-chemical Characteristics}

The Philippine Clean Water Act of 2004 was enacted to protect Philippine waters and preserve it for future generations (RA 9275) [11]. The Department of Environment and Natural Resources (DENR) was tasked to lead the implementation of the law and standard limits for certain physico-chemical parameters were determined based on their importance in sustaining aquatic life in the river system.

The classification of river systems based on beneficial use was defined, with the clean-up of Pasig River targeted at attaining a classification of Class $\mathrm{C}$, waters which can be used for the propagation of aquatic species, as well as for recreational purposes. The Estero de Paco, although classified as a dead river [3] because of the poor water quality, also aimed for a Class $\mathrm{C}$ level. The parameters used for determining the river classification includes color, $\mathrm{pH}$, temperature, $\mathrm{DO}, \mathrm{BOD}_{5}$, TSS, Oil \& Grease, Nitrate-Nitrogen, Phosphate-Phosphorus, Phenols, Total Coliforms, Chloride and Copper. These values are shown in Table 1 [12]. For purposes of this study, the parameters tested were limited to $\mathrm{pH}$, temperature, DO, BOD, Nitrate-N, and Phosphate-P. For the ensuing analysis, a modified Streeter Phelps model uses only the DO and BOD as critical data. The other parameters, however, will be helpful in the future when policy directions have to be set to maintain the water quality of the stream. It will also be helpful in identifying the focus of eventual remediation and prevention techniques to be used.

Table 1. DENR Standards

\begin{tabular}{|l|c|}
\hline Color & $\begin{array}{c}\text { No abnormal discoloration } \\
\text { from unnatural causes. }\end{array}$ \\
\hline Temperature & $\begin{array}{c}\text { Max } 3^{\circ} \mathrm{C} \text { rise over the ambient } \\
\text { temp for each month based on } \\
\text { the max daily readings over a } \\
\text { period of one year. }\end{array}$ \\
\hline $\mathrm{pH}$ & 6.5 to 8.5 \\
\hline $\begin{array}{l}\mathrm{DO}, \mathrm{min} \% \\
\text { saturation or mg/L }\end{array}$ & $\begin{array}{c}60.0 \% \\
5.0\end{array}$ \\
\hline 5-day BOD, mg/L & $7(10)$ \\
\hline $\begin{array}{l}\text { Total Suspended } \\
\text { solids }(\mathrm{TSS}), \mathrm{mg} / \mathrm{L}\end{array}$ & $\begin{array}{c}\text { Not more than } 30 \mathrm{mg} / \mathrm{L} \\
\text { increase over the average } \\
\text { monthly readings recorded } \\
\text { over a one-month period. }\end{array}$ \\
\hline Oil \& Grease, $\mathrm{mg} / \mathrm{L}$ & 2.0 \\
\hline NO ${ }_{3}-\mathrm{N}, \mathrm{mg} / \mathrm{L}$ & 10 \\
\hline PO -P, $\mathrm{mg} / \mathrm{L}$ & 0.4 \\
\hline Phenols, mg/L & 0.02 \\
\hline $\begin{array}{l}\text { Chloride as } \mathrm{Cl}, \\
\text { mg/L }\end{array}$ & 350 \\
\hline $\begin{array}{l}\text { Copper, }(\text { dissolved } \\
\text { copper), mg/L }\end{array}$ & 0.05 \\
\hline
\end{tabular}

\subsection{Dissolved Oxygen Models}

The simplest model for water quality makes use of DO as a basis for calculating the oxygen deficit of the water and BOD to determine the deoxygenation rates. Dissolved oxygen (DO) content is a very useful parameter to show the ecological health of any body of water. Oxygen is used by aquatic inhabitants such as fishes and shellfishes to sustain their existence. Aquatic plants need oxygen to survive. Further, anaerobic conditions cause the proliferation of undesirable microbes which contribute to the unpleasant odor found particularly in stagnant waters. The Streeter Phelps Model [13] is a simplified model which assumes that the stream is a plug-flow model and that upstream water is greatly influenced by any wastewater entering the stream, affecting the quality of the water downstream.

\subsubsection{The DO Sag curve}

The DO measurements is used to calculate the oxygen deficit and can be calculated using the equation below. The DO saturation value can be obtained in literature [14].

$$
D=D O_{s a t}-D_{o}
$$

Where: $\quad D=$ DO deficit, $\mathrm{mg} / 1$

$D O_{\text {sat }}=\mathrm{DO}$ saturation value, $\mathrm{mg} / 1$

$D_{o} \quad=$ DO concentration at point, $\mathrm{mg} / \mathrm{l}$

The \% saturation of DO can be found using the ratio of the DO at the specific temperature to the DO at saturated levels. According to USEPA, a healthy river maintains aC saturation of $70 \%, D_{U S E P A}$ but local standards use $60 \%$ as acceptable. Temperature effects also have to be taken into consideration in the calculation of the DO saturation. According to Lin [13], the American Society for Civil Engineering, Committee on Sanitary Engineering (ASCE-CSE) has established a table for the calculation of the $\boldsymbol{D} \boldsymbol{O}_{\text {sat }}$ levels at different temperatures, atmospheric conditions being $760 \mathrm{~mm} \mathrm{Hg}$ pressure at mean sea level.

\subsubsection{Re- Aeration Constant $\left(k_{r}\right)$}

The re-aeration constant is computed based on the O'Connor- Dobbins formula, where the velocity $(v)$ of the water and its depth $(H)$ are used.

$$
\begin{aligned}
& k_{r, 20}=\frac{3.9 v^{0.5}}{H^{1.5}} \\
& k_{r, T}=k_{r, 20}\left(1.039^{(T-20)}\right)
\end{aligned}
$$

where $k_{r .20}$ represents the re-aeration rate at $20{ }^{\circ} \mathrm{C}$ and $k_{r . T}$ inputs a temperature correction factor for other ambient temperatures. The re-aeration constant for small ponds and backwaters usually fall within the range of 0.10 - 0.30 [13]. The hydraulic characterization report of Herrera [1] gives the data for the physical description of the channels, with details shown in Table 2. The average values represent normal values when the tide is neither high nor low. These parameters were used to measure the degradation of river water quality. These parameters were further validated through actual sampling and measurements. 
Table 2. Hydraulic Data.

\begin{tabular}{|l|r|r|r|}
\hline Parameter & \multicolumn{1}{c|}{ Min } & \multicolumn{1}{c|}{ Max } & \multicolumn{1}{c|}{ Ave } \\
\hline Cross-sectional Area, $\mathrm{m}^{2}$ & 18.74 & 41.08 & 33.2 \\
\hline Depth, m & 2.09 & 8.04 & 4.34 \\
\hline Wetted perimeter, m & 14.26 & 23.85 & 19.02 \\
\hline Hydraulic radius, m & 1.26 & 2.30 & 1.74 \\
\hline Velocity, m/s & 0.03 & 0.17 & 0.10 \\
\hline
\end{tabular}

\subsubsection{Deoxygenation constant $\left(k_{d}\right)$}

The de-oxygenation rate constant represents the rate of degradation of the water as represented by the BOD from carbonaceous (CBOD) and nitrogenous (NBOD) reactions in the water. In the presence of a healthy plant life at the river banks, both components are likely to contribute to the deterioration of water quality [13]. This is experimentally determined under the assumption that most of the carbonaceous components react with 5 to 10 days of incubation during analysis, and CBOD can be estimated to the point where linearity in decomposition changes. The next stage is indicated by a temporary reduction in BOD but with an attendant in DO reduction as soon as decomposition of the deposit starts (NBOD). The NBOD is best estimated by adding a nitrification inhibitor prior to testing but his is no longer covered in the tests done. The slope of the curve where linearity is constant represents the de-oxygenation rate.

\subsubsection{The Streeter-Phelps Model}

This model [14] relates the changes in concentration of DO in the stream to the change in re-aeration and the rate of oxygen consumption or de-oxygenation of microorganisms at different points in the stream as measured by distance $(x)$ or time $(t)$. The complete equation is stated as:

$D=\frac{k_{d} L_{o}}{k_{r}-k_{d}}\left(e^{-k_{d} t}-e^{-k_{r} t}\right)+D_{o}\left(e^{-k_{r} t}\right)$

The equation allows us to predict the oxygen deficit levels at any point in the stream as long as there are no additional loads which will contribute to the degradation of the water quality. The time or distance at which the critical oxygen deficit $\left(t_{c r i t}\right.$ or $\left.x_{\text {crit }}\right)$ occurs can be calculated based with the additional input of the original BOD load $\left(L_{o}\right)$, with the velocity of the stream used estimate the distance travelled.

$t_{\text {crit }}=\left(\frac{1}{k_{r}-k_{d}}\right) \ln \left\{\frac{k_{r}}{k_{d}}\left[1-\frac{D_{o}\left(k_{r}-k_{d}\right)}{L_{o} k_{d}}\right]\right\}$

The result will be indicative of the amount of oxygen which will need to be replaced effectively through remedial measures in order to deliver cleaner water to the Pasig River.

\section{Methodology}

Since several studies have been done on the river quality, a review of the past results from other research agencies was conducted to validate the results. The hydraulic and hydrologic characterization conducted by Dr. Ariel Blanco [15] and Dr. Eugene Herrera [1] was tapped for data needed for the calculation of the re-aeration constant, $\boldsymbol{k}_{\boldsymbol{r}}$. The velocity and depth of the river at some points near the bridges were also measured using the floating object method where a small plastic bottle was tied to a 5-meter string and allowed to flow and timed until the string was stretched to the mark.

Site reconnaissance was done to evaluate the stretch of the river and pinpoint locations for sampling. Around 20 sampling points were identified based on conditions at or near the sites. These were areas expected to influence river quality due to the following conditions: a. stagnant flow; b. water flow from supposedly closed pipes; c. commercial or industrial sites nearby; d. direct access from the road; and e. presence of aerators or island reactors. The sampling was conducted using the recommended procedure for surface water sampling by DENR [16].

During the actual sampling, a Horiba U-52G unit was used to measure the DO, $\mathrm{pH}$, temperature, salinity, TDS, turbidity and other salient parameters needed for the model. Water samples were also retrieved and placed in plastic sampling bottles for eventual laboratory analysis of $\mathrm{BOD}_{5}$ to $\mathrm{BOD}_{20}, \mathrm{COD}$, TSS and other parameters. There were six such areas considered: Junction of Estero de Paco and an unnamed creek (JCT), President Sergio Osmena Highway (PSO), President Quirino Avenue (PQ), Pedro Gil Street (PG), Apacible Street (AP) and United Nations Avenue area (UNA). The Materials Recovery Facility (MRF) was also considered initially but because of its proximity to the next sampling point, was not continued. The area had an aerator set-up (Figure 2), but was intermittently turned on due to the high cost of maintenance. It had three pumps which were turned on alternately.

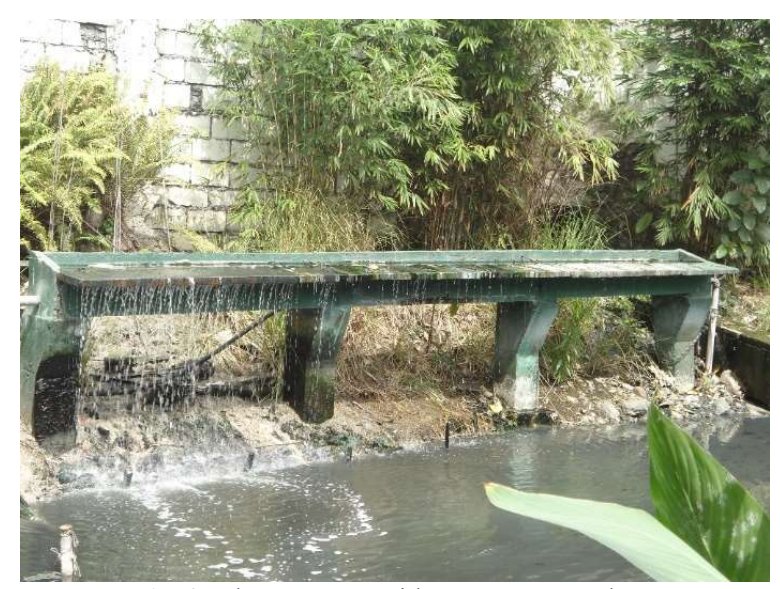

Fig. 2. The aerators, with one part turned on.

Sludge samples were also taken from the same areas. The samples were preserved in containers kept cold to $4{ }^{\circ} \mathrm{C}$, then transported directly to the laboratory for analysis. Analysis for the water samples included DO, BOD, COD, TSS, Oil and Grease (OG) and Organic Matter (OM). Data gathered were then used in the predictive model from the Streeter Phelps equation to simulate the level of contamination downstream to the Pasig River. The oxygen deficit calculated will be a helpful indication on what remediation measures to take. 


\section{Results and Discussion}

The on-site sampling of DO was scheduled for a period of six months to get data for the wet and dry season. The initial sampling was conducted during the dry season in April. A total of three samplings were done during the dry season and three for the wet season. Results of analysis show that during the dry season, even with the occasional rains, the DO of the river did not go any higher than 2.0 to $3.0 \mathrm{mg} / 1$. for the rainy season, sampling shows that heavy rains replenish the DO which ranged from 6.0 to $8.5 \mathrm{mg} / \mathrm{l}$ but did not improve the BOD since physical observations show that more solid wastes were present in the river during the rainy days. These were primarily due to the practice of indiscriminate throwing of septic waste into the river, as well as solid waste and road dust flowing down with rain runoffs.

\subsection{The Sag Curve}

The initial sampling showed very poor DO conditions throughout the waterway, with the highest value found at the junction near the headwater. Similarly, BOD results were also unacceptably high, ranging from 32 to $191 \mathrm{mg} / 1$ with the majority of the sampling points way above the 10 $\mathrm{mg} / \mathrm{l}$ standard for Class $\mathrm{C}$ waters. Table 3 shows the oxygen deficits while Figure 3 presents the Sag Curve.

Table 3. Calculated Oxygen deficits

\begin{tabular}{|c|c|c|c|c|}
\hline Location & $\begin{array}{c}\boldsymbol{D O} \\
\boldsymbol{m g} / \boldsymbol{l}\end{array}$ & $\begin{array}{c}\boldsymbol{D} \boldsymbol{O}_{\text {sat }} \\
\boldsymbol{m g} \boldsymbol{l}\end{array}$ & $\begin{array}{c}\boldsymbol{D}, \\
\boldsymbol{m g} \boldsymbol{l}\end{array}$ & $\begin{array}{c}\boldsymbol{D}_{\boldsymbol{D E N R}} \\
\boldsymbol{m g} \boldsymbol{l}\end{array}$ \\
\hline $\mathbf{J C T}$ & 2.14 & 7.75 & 5.61 & 2.86 \\
\hline PSO & 1.60 & 8.01 & 6.41 & 3.40 \\
\hline PQ & 0.56 & 7.49 & 6.93 & 4.44 \\
\hline PG & 0.61 & 7.50 & 6.89 & 4.39 \\
\hline AP & 0.31 & 7.58 & 7.27 & 4.69 \\
\hline UNA & 1.00 & 7.42 & 6.42 & 4.00 \\
\hline
\end{tabular}

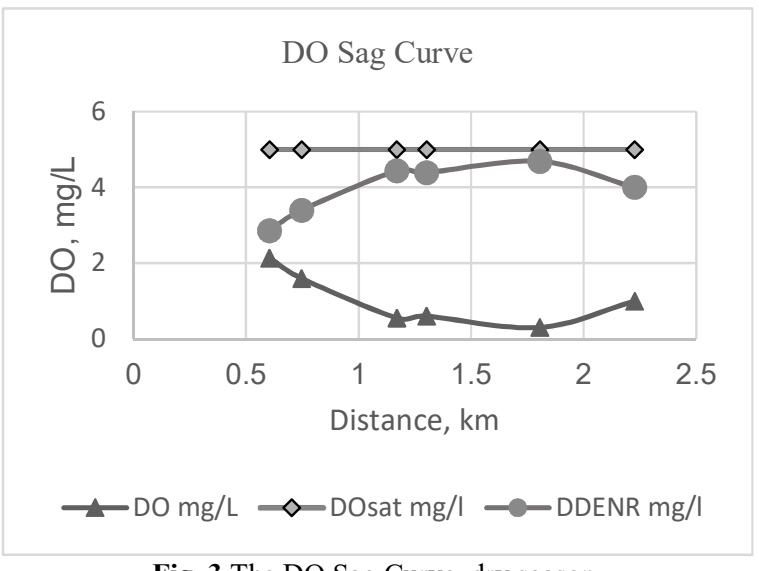

Fig. 3 The DO Sag Curve, dry season.

Of the 20 water sampling stations along the stretch of the river, initial data showed that the areas directly impacted in terms of river quality were those near the bridges which cut across the river. Interviews with the maintenance personnel in the area revealed that most nights, particularly in the middle of the week, some vehicles often stop at the road and throw plastic bags containing garbage directly to the river. The River Warriors, a group of volunteer residents tapped to keep watch over the river's cleanliness, were deputized to accost these people but unfortunately, although lessened, the practice still persists.

\subsection{Sludge Analysis}

Sludge samples were taken at areas near the various bridges crossing the Estero de Paco. The results of the sludge sampling show that the Oil \& Grease, and Organic Matter are at critical levels while the heavy metals are negligible except for Arsenic which was detected at 0.003 to $0.10 \mathrm{mg} / \mathrm{l}$, which is well within the DENR acceptable limits. Oil \& Grease levels were found to be present at high levels in all stations (10.0 to $293 \mathrm{mg} / \mathrm{l})$, even to the point of being visually manifested particularly at the PSO bridge and the UNA bridge area. Both of these areas are used by freight trucks and vans traveling to and from the ports of Manila. Organic matter was also found to be between 21 to $33 \%$ the highest being at the PG area. This area is home to a mini-constructed wetland which was a project of the PRRC. The area has been kept clean but no provision for containing the area covered has been planned. The plants have overgrown and sometimes cause eutrophication, causing low DO levels in the area.

\subsection{Critical Oxygen Deficit}

The DO saturation levels dictate the cleanliness of the stream and as such influences the curve level and the length of stream which can maintain oxygenation. During the sampling, it was noted that some areas had aerators which were operational but follows a schedule. At the time of sampling, the aerators were turned off. These aerators, when turned on, help create water riffles which generate oxygen as a contribution to re-aeration. Island reactors were present particularly in front of the Paco market, but the operation was controlled due to the high cost of electricity.

Heavy BOD load areas were noted between Pres. Quirino Avenue (PQA) and Pedro Gil (PG), although this was also the area found to have commercial eateries along the 3-meter bank easement area of the Estero. Washing of food and cooking utensils from these establishments were being done on the easement and may contributory to the BOD loading along that stretch because of the direct discharge of washings to the river.

Based on the model established, with no interventions available, the calculated critical time is at 12 minutes or around 730 meters away from the first station. This area can be found between stations PSO and PQ, where miniconstructed wetland have already been put in place. Physical presence of manure was observed during the visit, which may account for the low DO levels in the area. At this point DO will be at a 0 level and, if not replenished will move on to Pasig River which is $1.3 \mathrm{~km}$ away and 
Manila Bay which is $4.1 \mathrm{~km}$ away. During the wet season, It takes 1.47 days to reach anoxia, which spares the Pasig River but will affect the Manila Bay at $1.5 \mathrm{~m}$ away. In the special occasion just after the storm, the river lacks more oxygen at 7 minutes away from the Junction, which means dirty water will infiltrate both the Pasig River and the Manila Bay.

\subsection{Wet Season Analysis}

For the wet season, except for one or two stations, most of the sampling areas exhibited DO over the standard level of $5.0 \mathrm{mg} / \mathrm{l}$. Values fell within the range of 5.01 to $7.87 \mathrm{mg} / \mathrm{l}$ averaging at around $7.0 \mathrm{mg} / \mathrm{l}$. During a wet season sampling done right after a huge storm, it was observed that values were lower due to the presence of turbid waters and a lot of trash in the waterway, caused by flooding which occurred in most streets of Metro Manila. With the improvement in oxygen saturation, calculations from the model shows the critical time to be at 1.47 days or around $7 \mathrm{~km}$ from the first station. This would put it at around $1.5 \mathrm{~km}$ from the Manila Bay boardwalk. This shows that during the rainy season, the DO saturation level can be maintained throughout the stretch of the Estero and still contribute clean water to the Pasig River and Manila Bay.

One consideration which needs to be considered however, is the occurrence of flooding in the streets of Manila, where debris and dust from the roads are brought about by rain runoff to the waterways. The presence of these wastes bring the BOD levels up even if DO levels are high.

The sensitivity analysis conducted on the model tested the changes in both re-aeration and de-oxygenation constants, the UBOD and the initial DO along the reaches. This analysis shows that there is very little effect on the positioning of the curve when changes in the deoxygenation or re-aeration rate is increased or decreased.

\section{Conclusions and Recommendations}

The water and river sediment quality characteristics of the Estero de Paco shows that the levels of Dissolved Oxygen at all points in the River during the dry season is at a low saturation of $4 \%$ to $27 \%$ only. During the rainy season this improves to more than $100 \%$ saturation in some areas, with an average of $80 \%$ along the stretch. The Apacible Bridge (AP) sampling point was found to be consistently at a low of around $20 \%$ to $30 \%$, improving only when the island reactors in front of the Paco Market are turned on. Operationalization of the aerators, however, do not guarantee an increase of DO to saturation because of the presence of solid waste in some parts of the waterway. The DO Sag curve predicts a low point where anoxia occurs at the stretch from PSO to AP. This corresponds well with our subsequent monitoring results where most of the low DO values are found.

Based on the S-P model, the influence of the UBOD load in maintaining the health of the river is very evident. This represents the amount of organic matter introduced into the river from both point and non-point sources. A sensitivity analysis considering the velocity and depth of the water, the DO levels, and the BOD loads shows the control of waste loading to be a critical factor in maintaining the DO saturation of the river. The river hydraulic characteristics play a part in changing the reaeration constant, but as the sensitivity analysis shows, it has minimal effect on the DO values in the river. Keeping the river flowing and maintaining an ideal depth of at least 2 to 5 feet can cause re-aeration and beef up the DO. This can be done by minimizing the amount of siltation (through dredging) or preventing the accumulation of organic matter which is essentially the cause of the silt formation.

It is highly recommended, that the continued interaction with the residents be maintained to make them aware of how their participation in the clean-up through the prevention of waste intrusion is critical to the health of the river. With proper understanding of the importance of their role in keeping the water clean, run-off water to Pasig River and the Manila Bay will be of a good quality which can help maintain a Class C level stream. With the assistance of the Pasig River Rehabilitation Commission, the river is seen to be healthy at least two or three days a week, and sustaining this clean-up can promote further the health of the river.

\section{References}

1. E. Herrera, Hydraulic Characterization of Estero de Paco, Tech Report, Department of Science and Technology, September 2014.

2. E. Gagalac-Regis, The Pasig River: Caring for a Dying Ecosystem, (PRRC Report in the DANIDA Project, 2001).

3. PRRC Completion Report, Assessment of Policies and Programs, QC, Phil. December 2009.

4. J. A. I. De Castro, "Cleaning up Manila Bay: Mandamus as a tool for environmental protection" Eco Law Quarterly 57, 797-804 (2010).

5. G. S. Jacinto, R. V. Azanza, I. B. Velasquez, and F. P. Siringan, "Manila bay environmental challenges and opportunities", Wolanski, ed. The Environment in Asia Pacific Harbours. Springer Dodrect, The Netherlands pp 309-328. (2006)

6. G. S. Jacinto, M. L. San-Diego McGlone, I. B. Velasquez, C. L. Villanoy, and F. P. Siringan, "Biophysical environment of Manila Bay Then and Now", Wolanski, ed. The Environment in Asia Pacific Harbours. Springer Dodrect, The Netherlands (2006)

7. R. Oyoo, R. Leemans, and A. P. J. Mol, Future Projections of Urban Waste Flows and Their Impacts on African Metropolis Cities, Int. J. Env. Res. 5(3): 705-724 (2011)

8. S. L. Yang, K. H. Xu, J. D. Milliman, H. F. Yang, and C. S. Wu, Decline of Yangtze River water and sediment discharge: Impact from natural and anthropogenic changes, Sci. Reports 5 Art. No. $12581(2015)$ 
9. M. Eisakhani, and A. Malakahmad . Water quality assessment of Bertram River and its tributaries in Cameron Highlands, Malaysia. Worl App. Sc. J. 7, 769-776 (2009)

10. Teck-Yee Ling, N. Jaafar and L. Nyanti. Water and sediment quality near shrimp aquaculture farm in Selang Sibu River, Telaga Air, Sarawak, Malaysia. World App. Sci. J. 18 (6): 855-860, 2012

11. RA 9275, The Philippine Clean Water Act of 2004. http://r12.emb.gov.ph/ra-9275-the-philippine-cleanwater-act/

12. DAO 2016-08 Water quality guidelines and general effluent standards of 2016. https://server2.denr.gov.ph/uploads/rmdd/dao-201608.pdf

13. S. D. Lin, Water and Wastewater Calculations Manual $3^{\text {rd }}$ ed., McGraw Hill, NY. 2007

14. S. C. Chapra. Surface Water Quality Modeling. Waveland Press Inc., Long Grove, IL, USA.

15. Blanco, A, J. Santillan and G. Paraiso (2010), Pasig River Tributaries Assessment (PRTSAS) Hydrographic Component Study, Pasig River Tributaries Survey and Assessment Study, UP DGE, Diliman, QC.

16. DENR Water Quality Monitoring Manual Vol. 1. https://water.emb.gov.ph/wpcontent/uploads/2017/09/Water-QualityMonitoring-Manual-Vol.-1-ambient 14aug08.pdf

The author would like to acknowledge the assistance of the Department of Science and Technology (DOST), Maynilad, Inc., Enrique and Elena Ostrea, and the UP Engineering Research and Development Foundation for funding part of the research as well as PRRC and DENR-Environmental Management Bureau for providing access to some reports crucial to the study. 